\title{
Labour
}

Journal of Canadian Labour Studies

Le Travail

Revue d'Études Ouvrières Canadiennes

\section{Freedom to Strike? What Freedom to Strike? Back-to-Work Legislation and the Freedom to Strike in Historical and Legal Perspective}

\section{Eric Tucker}

Volume 86, automne 2020

URI : https://id.erudit.org/iderudit/1074478ar

DOI : https://doi.org/10.1353/1lt.2020.0042

Aller au sommaire du numéro

Éditeur(s)

Canadian Committee on Labour History

ISSN

0700-3862 (imprimé)

1911-4842 (numérique)

Découvrir la revue

Citer cet article

Tucker, E. (2020). Freedom to Strike? What Freedom to Strike? Back-to-Work Legislation and the Freedom to Strike in Historical and Legal Perspective. Labour / Le Travail, 86, 135-147. https://doi.org/10.1353/llt.2020.0042 d'utilisation que vous pouvez consulter en ligne. 


\title{
Freedom to Strike? What Freedom to Strike? Back-to-Work Legislation and the Freedom to Strike in Historical and Legal Perspective
}

\author{
Eric Tucker, York University
}

DEFENDERS OF LABOUR RIGHTS rightly criticize the enactment of back-to-work (BTW) legislation ending otherwise lawful strikes as egregious interference with the freedom to strike, a freedom that in 2015 the Supreme Court of Canada (SCC) held is constitutionally protected. ${ }^{1}$ Yet, often overlooked in discussions of the freedom to strike and the propensity of neoliberal governments to limit that freedom through exceptional measures is the baseline of restrictions built into the DNA of Canada's version of the Wagner Act Model (WAM) of collective bargaining. ${ }^{2}$ The first goal of this essay, therefore, is to locate BTW measures in the longer history and current practice of legally restricting the freedom to strike. The second goal is to consider the extent to which the constitutional freedom to strike is likely to modify the legal framework generally and to limit the use of BTw measures in particular.

\section{The Legal Regulation of the Freedom to Strike}

The non-constitutional framework regulating the freedom to strike has three strands: the constitutive liberal order framework of the common law; the industrial pluralist framework for private-sector bargaining (the WAM); and public-sector and essential-service collective bargaining laws. Together, these strands produce a legal regime that narrowly restricts workers' freedom to strike.

\section{The Constitutive Liberal Order of the Common Law}

To begin at the beginning, it is essential to recognize that collective action by workers in capitalist social formations runs against the grain of their foundational commitment to a liberal order founded on individualism. Ian McKay helpfully defines this order as "one that encourages and seeks to extend across time and space a belief in the epistemological and ontological primacy of the

1. Saskatchewan Federation of Labour v Saskatchewan, 2015 SCC 4, [2015] SCR 245.

2. Leo Panitch and Donald Swartz coined the term "permanent exceptionalism" to characterize this development. Panitch \& Swartz, From Consent to Coercion: The Assault on Trade Union Freedoms, 3rd ed. (Toronto: Garamond, 2003). On the history of Canadian Wagnerism, see Judy Fudge \& Eric Tucker, Labour Before the Law (Toronto: Oxford University Press, 2001); Peter S. McInnis, Harnessing Labour Confrontation (Toronto: University of Toronto Press, 2002). 
category 'individual."'3 The liberal order framework does not entail a formal legal constitutional commitment but rather is constitutive in the sense that it embeds a foundational ideological commitment that shapes but does not determine the formal legal response to worker collective action.

The constitutive commitment to individualism privileges individual rights and freedoms, including the right to private property and freedom of contract. The individual as property owner enjoys the right to exclude, freedom to use, privilege to transfer, and immunity from taking. Within broad limits, property owners can use their property as they see fit without regard to its impact on anyone else. As sovereign individuals, they are also free to contract with other sovereign individuals, on terms and conditions they find mutually agreeable. Individuals within the liberal order framework are formally equal, but historically the liberal order framework did not apply universally to all those within its territorial boundaries. Enslaved and Indigenous peoples, for example, were liable to have their labour and lands taken, without their consent and without compensation. ${ }^{4}$

The liberal order framework does not exist in the abstract but rather is located in capitalist social formations, characterized by private ownership of the means of production by the few, the capitalists. The many sovereign individuals who own only their own labour power, the workers, are dependent on its sale. The liberal order framework recognizes workers as equal sovereign individuals who are free to sell their labour power to other property owners on mutually agreeable terms. However, it ignores the structural advantages enjoyed by the owners of capital in the bargaining game. Capitalists can exercise their ownership rights to decide whether to invest, what to produce, where to produce, how much to produce, and how many workers to hire. Workers lack the means to survive for long outside the labour market and thus are dependent on finding a capitalist willing to hire them, while competing against other, equally dependent workers. Their abstract freedom is significantly constrained by their material circumstances.

Because the liberal order is committed to the formal equality of sovereign individuals, it starts from the premise that employers and workers should only bargain with each other individually. Combinations of workers to improve the terms and conditions of their employment are anticompetitive and contrary to the notion of individualism.

Of course, in reality, the commitment to individualism is not absolute. The law allows wealth owners to combine through the vehicle of the corporation, but it masks the collective character of capital by treating the corporation as

3. Ian McKay, "The Liberal Order Framework: A Prospectus for a Reconnaissance of Canadian History," Canadian Historical Review 81, 4 (2000): 624.

4. Nancy Fraser, "Roepke Lecture in Economic Geography-From Exploitation to Expropriation: Historic Geographies of Racialized Capitalism," Economic Geography 94, 1 (2018): 1-17. 
a legal person that can participate in the market just like any flesh-and-blood human individual. ${ }^{5}$ However, the law does not offer workers an equivalent vehicle. Quite the opposite. Historically, common law judges and early 19thcentury English legislation treated worker combinations as criminal or civil conspiracies, or both. ${ }^{6}$

The above describes the liberal order framework as an ideal type, but it should not be taken as an accurate depiction of how actually existing liberal orders functioned. Workers often rejected the order's legal prescriptions, let alone its ideological tenets, and engaged in collective actions to advance their common interests. When conditions were favourable, Canadian workers formed trade unions, struck for better terms and conditions, and watched and beset (picketed) their employers' businesses or boycotted their businesses and those of their employers' suppliers or distributers, notwithstanding the dubious legality of such actions. From time to time, the state responded with coercive measures, ranging from reading the riot act and calling out the militia or the police to disperse crowds to prosecuting individual workers for various criminal offences. As well, the law offered their employers legal remedies, including court-issued injunctions and damage awards that the state could be called upon to enforce. The liberal order framework rationalized all these coercive measures as ones necessary to defend individual sovereignty, but workers experienced these actions as the iron fist of class justice. The failure of the liberal order framework to achieve hegemonic status, and the unwillingness of governments consistently to mount the coercion necessary to impose it, ultimately meant that workers enjoyed a de facto freedom to form unions and strike, which the law begrudgingly recognized over time, focusing instead on restricting what workers could do to make their strikes effective. ${ }^{7}$ Indeed, it would be fair to say that the very failure of the liberal order framework to contain industrial conflict pushed governments to experiment with reforms that would do a better job.

The story of those struggles and the legal changes they produced has been told elsewhere. ${ }^{8}$ Yet despite these changes, the ideological hold of the liberal order framework has never been entirely loosened and continues to influence the permissible scope of workers' collective action.

5. Harry Glasbeek, Wealth by Stealth (Toronto: Between the Lines, 2002).

6. John V. Orth, Combination and Conspiracy (Oxford: Oxford University Press, 1991).

7. Eric Tucker, “'That Indefinite Zone of Toleration': Criminal Conspiracy and Trade Unions in Ontario, 1837-1877," Labour/Le Travail 27 (Spring 1991): 15-54; Judy Fudge \& Eric Tucker, "The Freedom to Strike in Canada: A Brief Legal History," Canadian Labour and Employment Law Journal 15, 2 (2010): 333-353.

8. Barry Eidlin, Labor and the Class Idea in the United States and Canada (Cambridge: Cambridge University Press, 2018); Fudge \& Tucker, Labour Before the Law; McInnis, Harnessing. 


\section{Industrial Pluralism: The WAM Restrictions on the Freedom to Strike}

The industrial pluralist order was entrenched in Canada at the end of World War II in the face of a massive display of worker militancy. The WAM was the state's legal response, designed to facilitate a particular kind of responsible unionism and decentralized collective bargaining that would bring workers some amelioration, while providing employers with assurances that workers' collective power would be contained and disruptions of production allowed in limited circumstances. The so-called accord entailed restrictions on the freedom to strike but also provided workers with certain rights, including a limited right to strike.

The restrictions on the freedom to strike were (and are) severe, prohibiting recognition strikes, strikes during the life of a collective agreement, political strikes, solidarity strikes, strikes before the parties have undergone conciliation and a cooling-off period, strikes not yet approved by a strike vote, and, in some jurisdictions, strikes before the union has given the employer timely notice. In short, workers seeking to unionize or who are unionized are prohibited from striking, or threatening to strike, except during the negotiation of collective agreements and then only after certain procedures have been followed. The penalties for engaging in unlawful strikes are quite severe. Labour boards are empowered to declare strikes unlawful and order them to end. These orders are enforceable by courts, which can hold unions and officials in contempt, exposing the union to fines and officials to fines and jail..$^{9}$ Employers can bring grievances against the union and claim damages. They can also discipline individual workers who participate in unlawful strikes, including termination, depending on the circumstances. In short, the WAM created the most restrictive and effective regime of strike controls in Canadian history.

What then is "pluralist" about such a repressive regime? The answer, briefly, is that it gave workers a set of rights in lieu of freedoms taken from them, including the following:

9. For example, in September 2019, workers at the Nemak plant in Windsor went on a wildcat strike and put up a barricade in front of the plant after it announced it was going to close and move its operations to Mexico. The union, Unifor, supported these actions. The employer obtained a declaration from the labour board and then sought its enforcement in court. The judge endorsed the board's order, but when the strike did not end, the employer applied to have the union and its leaders held in contempt. The judge gave the union a day to end the strike but when it failed to do so, the judge fined the union $\$ 75,000$ plus an additional $\$ 10,000$ fine for each day the strike continued. The judge also imposed a $\$ 1,000$-a-day fine on four union officials involved. Within 48 hours the union reached an agreement with the employer calling for some brief negotiations, which would be followed by expedited grievance arbitration (limited to whether the employer's action violated the collective agreement). The employer also agreed not to discipline the workers who had participated in the strike. In short, the union returned to the fold of industrial legality, with little, if anything, to show for it. Trevor Wilhelm, "Protest against Nemak Ends, Unifor Members Return to Work," Windsor Star, 16 September 2019, https://windsorstar.com/news/local-news/ protest-against-nemak-ends-unifor-members-return-to-work. 
- a right to recognition, if they could establish majority support for unionization;

- a right to arbitration to resolve disputes over the interpretation and application of the collective agreement; and

- a right to maintain employment status while on strike and to be reinstated at its termination, within a limited time period.

It should be noted that, strictly speaking, the last right - protection of employment status - is not directly a substitute for a restriction on the freedom to strike but rather a right that protects the exercise of what remains of the freedom to strike.

The pluralist regime was the outcome of intense class struggle and strike waves that employers and the state could not control by repressive measures alone. This forced the state to construct a system of labour relations that did not just restrict industrial conflict but provided unionized workers with industrial citizenship rights. More importantly, the regime operated during a period of unprecedented economic growth and stability, in which unionized workers shared by having wages linked to productivity increases and from modest Keynesian welfare-state measures. ${ }^{10}$ While workers did not accept the restrictions of the regime at all times and in all places, as evidenced by bouts of wildcat striking, it achieved a hegemonic status that had eluded the liberal order regime. ${ }^{11}$

\section{Essential-Service Restrictions}

Overlaid on the pluralist regime restrictions were a second set of restrictions justified on the ground of an overriding public interest in preventing strikes when they created an immediate danger to public security, health and safety, or, more controversially, the economy. ${ }^{12}$ We can trace the safety and security restrictions to the late 19th century, shortly after workers gained the formal freedom to strike. In the aftermath of a railway strike that left passengers stranded on trains between stations, the federal government enacted a law that abolished criminal prosecution for workers' breach of their contracts of employment, which had been a major feature of the master-and-servant

10. For a discussion that emphasizes the limits of Keynesian policy during this era, see Fletcher Baragar, "Theory, Policy and Institutional Structure: PC 1003 and Macroeconomics," in Cy Gonick, Paul Phillips \& Jesse Vorst, eds., Labour Gains, Labour Pains: Fifty Years of PC 1003 (Winnipeg: Society for Socialist Studies, 1995), 39-57.

11. Overall, between 1960 and 2004, 18 percent of strikes were wildcats. Linda Briskin, "Public Sector Militancy, Feminization, and Employer Aggression," in Sjaak van der Velden, Heiner Dribbusch, Dave Lyddon \& Kurt Vandaele, eds., Strikes around the World: Case-Studies of 15 Countries (Amsterdam: Aksant, 2007), 86, 95-96.

12. Eric Tucker, "Regulating Essential Service Strikes in Canada," in Moti Mironi \& Monika Schlachter, eds., Regulating Strikes in Essential Services: A Comparative 'Law in Action' Perspective (Alphen aan den Rijn, The Netherlands: Kluwer Law International, 2018), 107-144. 
regime that predated the liberal order. However, it also enacted legislation making it a crime to breach a contract knowing that a likely consequence would be to endanger human life, cause serious injury, or expose valuable property to destruction. This could potentially apply to strikers, since quitting work without giving notice was a breach of contract. However, for the breach to be criminal, there also had to be knowledge of the strike's consequences. ${ }^{13}$

We can trace the impulse to restrict the freedom to strike in the name of protecting the economy to the federal government's Industrial Disputes Investigation Act of 1907.14 The act required unions and employers to resort to conciliation before exercising their freedom to strike or lockout, but it only applied to those sectors of the economy seen to have a significant impact on the economy, including public utilities, railways, and mines. Governments subsequently incorporated this restriction into the WAM, so that it limits the freedom to strike generally.

When the state adopted the WAM at the end of World War II, it generally enacted additional restrictions on the freedom to strike to protect essential services. This was because most Canadian governments did not extend the WAM to the public and para-public sectors, and the private sector generally did not provide essential services, narrowly conceived, although there were some exceptions, such as railway workers, as Charles Smith's contribution to this roundtable demonstrates. As well, some public-sector workers, such as municipal transit and sanitation workers, whose services could be viewed as essential in some contexts, were included in private-sector collective bargaining laws and therefore faced the WAM's "normal" restrictions on the freedom to strike. Municipal police and firefighters also secured collective bargaining rights, but they were not included in general labour relations acts. Rather, the state enacted dedicated statutes that completely deprived these workers of the freedom to strike. Instead, collective bargaining disputes were to be resolved through binding-interest arbitration by a neutral third party. This was the beginning of the no-strike model for essential services.

The need to consider further restrictions on the freedom to strike in the name of protecting essential services grew substantially in the late 1960s when governments extended collective bargaining to the public and para-public sector more broadly. Two key issues needed to be resolved: the definition of essential services and the method to protect them. A full survey of responses is not possible, but in broad terms, the two most common responses were the no-strike model, discussed above, and the designation model, or controlled strike model. The basic premise of the controlled strike model is that essential

13. The law was subsequently amended so that it did not apply to workers engaging in a lawful strike. This is largely superfluous since workers who strike legally do not breach their contract of employment. The law - "criminal breach of contract" - is still on the books. Criminal Code, Rsc 1985, c C-46, s 422.

14. Bob Russell, Back to Work? (Scarborough, ON: Nelson, 1990). 
services must be maintained during a strike. In general terms, this objective is achieved by requiring the parties to negotiate an essential-services agreement, which sets out which services are essential and the level at which they must be provided during a strike. Normally, essential-service laws also provide that if the scope of the designation is so great as to render the strike ineffective, workers can access interest arbitration to resolve the dispute.

Some governments also adopted the so-called unfettered strike model (essentially the WAM), typically for workers who were not providing essential services in the strict sense of the term, such as postal workers and teachers and, as mentioned earlier, civic and local transit workers. Of course, the unfettered strike model contained all the WAM fetters on the freedom to strike, but it did not add any additional ones. However, this model, as well as the controlled strike model, was backstopped by the power of government to end otherwise legal strikes by back-to-work measures, which could take the form of legislation or, in some jurisdictions, executive orders.

The power to use Bт w measures was not new, but governments had rarely exercised it prior to the $1970 \mathrm{~s} .{ }^{15}$ That began to change after para-public-sector workers such as teachers and hospital workers (in some provinces) gained the freedom to strike. In most cases, when governments ended lawful strikes by BTW measures, they substituted binding-interest arbitration by a neutral third party. Between 1950 and 1974, which captures the era before the neoliberal turn (and mostly before the widespread extension of collective bargaining to the public and para-public sectors), governments took BTW measures 32 times, or about 1.3 times a year. ${ }^{16}$

To summarize, by the early 1970s Canadian workers enjoyed a very cramped freedom to strike. Private-sector workers could only strike when no collective bargaining agreement was in force and after they had followed prescribed procedures. Public- and para-public-sector workers' freedom to strike was even more constrained. Some were deprived entirely of the freedom to strike, others could engage in controlled strikes that significantly undermined their bargaining leverage, while others were notionally free to strike but liable to be legislated back to work if the government in power perceived the resulting disruption to be unacceptable.

\section{Back-to-Work Legislation under Permanent Exceptionalism}

That was the apogee. In the mid- to late 1970s, Canadian governments began to take the neoliberal turn that, in the area of collective bargaining, produced what Leo Panitch and Donald Swartz characterized as "permanent exceptionalism," imposing greater restrictions on workers' freedom to

16. Calculated from Panitch \& Swartz, From Consent to Coercion, Table 8, 184. 
strike. ${ }^{17}$ Governments achieved this result in a variety of ways. Beginning in the mid-1970s, governments began resorting to wage controls that stripped affected workers of the freedom to strike for the duration of those controls. ${ }^{18}$ Another, less direct way of restricting the freedom to strike was by expanding the number of bargaining units that were designated as providing essential services and/or by enlarging the number of workers required to maintain essential services. Finally, and most importantly for the purposes of this roundtable, governments markedly increased their use of BTw measures in the second half of the 1970s and continued doing so, with some fluctuations, until the early 2000s. ${ }^{19}$ From 1975 to 2002, governments resorted to BT w measures 115 times, or about 3.2 times a year. Looking more narrowly, from 1982 to 2002, governments enacted restrictive labour laws about 6 times per year. ${ }^{20}$

Government use of втш measures and restrictive labour laws has declined in frequency since that time. Between 2003 and 2014, BTw measures were used a total of 15 times - or, on average, a little more than once a year, which is close to the frequency seen before the neoliberal turn - while restrictive labour laws were enacted fewer than 4 times per year. ${ }^{21}$ One major reason for this decrease is the sharp decline in strike frequency and days lost to strikes, beginning in the mid-1970s and continuing to the present, so that strikes are as infrequent now as they were any at any point in the 20th century. ${ }^{22}$

\section{Back-to-Work Legislation and the Constitutional Right to Strike}

Some might suggest that another reason for the decline in government's use of BTw measures is the Canadian Charter of Rights and Freedoms. However, that would be incorrect. The SCC only recognized in 2015, in the Saskatchewan Federation of Labour (SFL) case, that workers enjoyed a constitutionally protected freedom to strike. Prior to that time, the court had steadfastly insisted that section 2(d) of the Charter, which protects freedom of association, did not

17. Panitch \& Swartz, From Consent to Coercion.

18. For a discussion, see the essay by Christo Aivalis in this volume.

19. Panitch \& Swartz, From Consent to Coercion, Table 8, 184.

20. Calculated from Canadian Foundation for Labour Rights, "Restrictive Labour Laws in Canada," accessed 25 May 2019, https://labourrights.ca/issues/restrictive-labour-laws-canada (hereafter CFLR database).

21. Calculated from Panitch \& Swartz, From Consent to Coercion; CFLR database.

22. Jordan Brennan, "Canadian Labour Disputes, Wage Growth and Inflation, 1903-2016," chart in Jason Kirby, "The 91 Most Important Economic Charts to Watch in 2018," Maclean's, 5 December 2017, https://www.macleans.ca/economy/economicanalysis/the-most-importanteconomic-charts-to-watch-in-2018/\#jordanbrennan. Also, see Eric Tucker, "Can Worker Voice Strike Back? Law and the Decline and Uncertain Future of Strikes," in Alan Bogg \& Tonia Novitz, eds., Voices at Work: Continuity and Change in the Common Law World (Oxford: Oxford University Press, 2014), 455-473. 
protect the freedom to strike. ${ }^{23}$ Hence, the decline in втш measures between 2002 and 2014 could not possibly have been the result of constitutional protection. Moreover, since the date of the SFL judgement (30 January 2015), governments have enacted BTW legislation five times, or at a rate similar to that of the period between 2002 and 2014. Of course, it is possible that were it not for the $S F L$ decision, governments would have resorted to BTW legislation more frequently, but that is unknown.

This leads us to the question of the extent to which the constitutional protection of the freedom to strike limits government use of BTW measures, as well as other restrictions on the freedom to strike. ${ }^{24}$ At the time of writing, no constitutional challenge to post-SFL BTW measures have reached the courts. ${ }^{25}$ However, a challenge to the federal government's 2011 втш legislation targeting postal workers was decided in 2016 and so, based on this case, and on the $S F L$ decision itself, we can discuss in general terms the constitutional limits on BTW measures.

The general test to determine the constitutionality of legislation that interferes with the freedom to strike is "whether the legislative interference with the right to strike in a particular case amounts to substantial interference with collective bargaining." 26 To determine whether there has been substantial interference, the court asks whether there has been a disruption of the balance between employer and employees. The SCC articulated some of the ways laws might disrupt that balance, including laws that "ban recourse to collective action without adequate countervailing protections." ${ }^{27}$ The $S F L$ case did not involve BTW legislation but rather provincial legislation that aggressively regulated essential-service strikes without providing a dispute resolution mechanism in the event that designations deprived workers of an effective ability to strike. By implication, BTW legislation that completely deprived workers of the freedom to strike would be prima facie unconstitutional.

The postal workers' case challenged в selection (FOS) to resolve outstanding differences, except for wage increases and the length of the agreement, which were set by statute. ${ }^{28}$ At the time, Canadian courts had not recognized a constitutional right to strike and so the

23. This goes back to the first trilogy of labour rights cases, decided in 1987.

24. For further reflections on this issue, see Alison Braley-Rattai's essay in this volume.

25. The implications of the length of time delay between the use of втш measures and a judicial determination of their constitutionality is an important consideration when assessing their efficacy.

26. SFL, para. 78 .

27. SFL, para. 78, citing an earlier SCC judgment: Mounted Police Association of Ontario v Canada (Attorney General) 2015 SCC 1, [2015] 1 SCR, para 90.

28. Restoring Mail Delivery for Canadians Act, sC 2011, c17; Canadian Union of Postal Workers v Her Majesty in Right of Canada, 2016 onsC 418 (hereafter CUPW). 
federal government would not have considered that its legislation was vulnerable to a successful constitutional challenge. However, when the parties argued the case in October 2015, the constitutional landscape had changed and the principal question before the court was whether this BTw legislation violated the workers' constitutionally protected freedom to strike.

Based on the court's judgment, it is likely that all BTw legislation prima facie violates Charter-protected freedom of association. The court specifically rejected the proposition that a law enacted following a lengthy period of collective bargaining and work stoppages would be valid: "There is no support for a temporal limit on the right to strike. ... Nor is there any support for the proposition that the right to strike, once engaged (as long as it is contributing to a meaningful process of collective bargaining) can be taken away without a s. 2(d) violation." 29

While one might construct a hypothetical situation in which a strike is no longer contributing to a meaningful process of collective bargaining, it seems far-fetched. The other issue, not addressed by the court, is whether it would uphold BTw legislation that provided "adequate countervailing protections." We will briefly consider the implications of that formulation for the constitutionality of the "standard" restrictions on the freedom to strike built into the WAM and public-sector collective bargaining law, but in the context of В $\mathrm{WW}$ measures, it is hard to imagine what countervailing protection would be adequate. For example, the substitution of binding-interest arbitration for the freedom to strike does not protect the countervailing power generated by the collective withdrawal of labour but simply eliminates countervailing power from the equation, leaving it to the arbitrator to settle the dispute based on criteria such as comparability. ${ }^{30}$

That being the case, it is probably fair to assume that all втw measures will be found in violation of the right to strike and the question will be whether those measures can be justified under section 1 as "demonstrably justified in a free and democratic society." This requires the government to establish on a balance of probabilities that (1) it had a pressing and substantial objective; (2) its actions were rationally connected to the achievement of those objectives; (3) the rights-infringing measures minimally impaired the affected right; and (4) the harmful effects of the measure do not outweigh its benefits. How might a section 1 analysis play out in the context of BTw measures?

To begin, with regard to the first branch of a section 1 analysis, the court in the postal workers' case expressly rejected the argument that only the

29. CUPW, para. 185 .

30. There is, however, evidence that arbitrators award a wage premium in compulsory arbitration, which cannot be explained by the bargaining power of the workers deprived of the right to strike. See Michele Campolieti, Robert Hebdon \& Benjamin Dachis, "Collective Bargaining in the Canadian Public Sector, 1978-2008: The Consequences of Restraint and Structural Change," British Journal of Industrial Relations 54, 1 (2016): 192-213. 
protection of essential services could satisfy the "pressing and substantial objective" criterion. This was crucial because postal services are not essential in the strict sense of the term and governments have not treated them as such legislatively. The court's broader conception of pressing and substantial objectives permits governments' successfully arguing that BTW measures preventing significant disruptions to non-essential services or to the broader economy can be demonstrably justified.

The rational connection test is unlikely to be an issue, since втW measures achieve the goal of ending the disruption. Thus, the minimal impairment requirement will be the crucial site of dispute, and it was at this stage that government lost its case in both SFL and the postal workers litigation. The problem in the SFL case was that the legislation gave the employer unilateral authority to determine whether and how to maintain essential services, with no review mechanism, and further, that it failed to provide a meaningful dispute resolution mechanism to resolve bargaining impasses, features normally present in Canadian essential-service strike laws. In the postal workers' case, the law provided an arbitration mechanism but tilted it in favour of the employer. Most fundamentally, the tabling of втш legislation itself "created and exacerbated an imbalance between the parties that had not existed before the legislation was tabled." ${ }^{11}$ This holding is potentially devastating to any section 1 defence of втW measures since it is difficult to imagine what substitute could address the resulting loss of union bargaining power. I suspect, therefore, that the test for minimum impairment will focus on whether the loss of the freedom to strike is "balanced by access to a system which is capable of resolving in a fair, effective, expeditious manner disputes which arise between employers and employees." 32

The problem with the government's section 1 argument in the 2011 postal workers' legislation was that the law imposed a mandatory wage increase, set the term of the agreement, and allowed the appointment of an arbitrator without consultation with the parties. Federal government lawyers no doubt had a careful eye on this judgement when they drafted Bill C-89, the BTw law ending the 2018 postal workers' job action. In particular, the law provided for the parties to each submit the names of three acceptable arbitrators. If there were no common nominees, the chair of the Canada Industrial Relations Board was to arbitrate. All matters in dispute were to be resolved by arbitration and the act stipulated a set of principles to guide the arbitrator, including the major concerns raised by the union (health and safety; equal pay; fair treatment of temporary and part-time employees) and the employer (financial stability; culture of collaboration; high-quality service at a reasonable price). ${ }^{33}$

31. CUPW, para. 212.

32. Reference Re Public Service Employees Relations Act (Alta.), [1987] 1 sCR 313 at 380

(Dickson) cited in $S F L$ at para. 94.

33. Postal Services Resumption and Continuation Act, SC 2018, c 25. 
Based on the thin body of case law to date, there is little doubt in my mind that a court would find this legislation minimally impairing in the event that the union pursues its challenge. If I am correct, there is a significant likelihood that well-designed втш measures, of the kind that were typical before 2015, will likely pass constitutional muster. Only the more draconian variations will be constitutionally out of bounds.

While this essay has focused on BTw measures, it is worth considering whether the restriction on the freedom to strike embedded in the WAM and public-sector collective bargaining laws violates workers' constitutionally protected freedom to strike. In principle, the courts could find that all of these restrictions are unconstitutional, but that result is unlikely for two reasons. First, as long as the courts view the restrictions as reasonable ones that still allow collective bargaining to occur, they are unlikely to hold that the measures "substantially" interfere with collective bargaining. Second, even if the courts were prepared to hold that the measures do substantially interfere, as long as the substitute for the freedom to strike is viewed as reasonable, then the court is likely to find it demonstrably justified under a section 1 analysis.

For example, the procedural hurdles to conducting a lawful strike, such as conciliation or a strike vote, are almost certain to pass constitutional muster, unless they are designed to create a significant barrier to holding a lawful strike, as is the case in Australia and the United Kingdom. ${ }^{34}$ Similarly, the prohibitions on recognitions and midterm strikes are likely to survive because the substitution of administrative recognition and grievance arbitration are now woven into the fabric of Canadian collective bargaining law and practice. I also expect that courts will uphold the constitutionality of the no-strike model for police and firefighters and other public-safety workers, provided the alternative is arbitration or Fos by a neutral third party. A court might have more reservations about broader applications of the no-strike model to groups such as the Toronto transit workers, even with otherwise acceptable substitutes, but that would depend on its view of the state's legitimate interest in preventing a labour disruption..$^{35}$ In fact, the government of Alberta responded to the SFL judgment by replacing the no-strike model for government workers with the designated strike model, believing that the normative designated strike model would pass constitutional muster. ${ }^{36}$

34. Breen Creighton, Catrina Denvir, Richard Johnstone \& Shae McCrystal, "Protected Industrial Action Ballots: An Empirical View," Journal of Industrial Relations 60, 1 (2018): 53 76; Tonia Novitz, "UK Regulation of Strike Ballots and Notices - Moving beyond 'Democracy,"” Australian Journal of Labour Law 29 (2016): 226-242.

35. Toronto Transit Commission Labour Disputes Resolution Act, 2011, so 2011, c 2.

36. Tellingly, the act was entitled An Act to Implement a Supreme Court Ruling Governing Essential Services (sA 2016, c 10). 


\section{Conclusion}

Starting with the liberal order framework and continuing through industrial pluralism and its extension to the public sector, Canadian labour law has taken a dim view of strike activity and adopted measures to contain its frequency and efficacy. BTw legislation is only one of the many ways that the freedom to strike is restricted in Canada. The WAM model itself incorporates the most wide-sweeping restrictions on the freedom to strike in Canadian history, while additional restrictions are imposed on workers providing public services, including a complete ban (the no-strike model) or a partial ban (the designation or controlled strike model). BTW measures are reserved for workers who lawfully exercise their legal freedom to strike in the rare moments when they can. However, governments may revoke even this limited legal freedom if it views the resulting disruption as unacceptable.

The constitutional freedom to strike, recognized by the SCC in 2015, is unlikely to upend Canada's restrictive strike laws. Rather, it is more likely to valorize them, while restraining governments from engaging in 'excess' repression of the freedom to strike, by which I mean state measures that are outside the existing, restrictive norms of industrial legality. In an era of growing government intolerance of organized labour, and in which we are witnessing the rise of authoritarian neoliberal modes of governance, this is no small protection, but the constitutional right to strike is unlikely to provide workers with greater legal freedoms than those they were once able to force government to recognize by their own efforts. ${ }^{37}$ 